OPEN ACCESS

Edited by:

Åke Sjöholm,

Gävle Hospital, Sweden

Reviewed by:

Alex Rafacho,

Federal University of Santa

Catarina, Brazil

Marc Prentki,

Université de Montréal, Canada

Everardo Magalhaes Carneiro,

Campinas State University, Brazil

*Correspondence:

Yuyan Zhao

zhaoyybox@163.com

Specialty section:

This article was submitted to

Diabetes,

a section of the journal

Frontiers in Endocrinology

Received: 21 February 2019

Accepted: 17 July 2019

Published: 06 August 2019

Citation:

Bian C, Bai B, Gao Q, Li S and Zhao Y (2019) $17 \beta$-Estradiol Regulates Glucose Metabolism and Insulin Secretion in Rat Islet $\beta$ Cells Through GPER and Akt/mTOR/GLUT2

Pathway. Front. Endocrinol. 10:531

doi: 10.3389/fendo.2019.00531

\section{$17 \beta$-Estradiol Regulates Glucose Metabolism and Insulin Secretion in Rat Islet $\beta$ Cells Through GPER and Akt/mTOR/GLUT2 Pathway}

\author{
Che Bian ${ }^{1,2}$, Bowen Bai ${ }^{1}$, Qian Gao ${ }^{1}$, Siyi $L^{1}{ }^{1}$ and Yuyan Zhao ${ }^{1 *}$ \\ ${ }^{1}$ Department of Endocrinology, The First Affiliated Hospital of China Medical University, Shenyang, China, ${ }^{2}$ Department of \\ Endocrinology and Metabolism, The Fourth Affiliated Hospital of China Medical University, Shenyang, China
}

Aims: To explore the molecular mechanism by which 17ק-estradiol (estrogen 2, E2) regulates glucose transporter 2 (GLUT2) and insulin secretion in islet $\beta$ cells through $\mathrm{G}$ protein-coupled estrogen receptor (GPER) via Akt/mTOR pathway.

Methods: SPF-grade SD male rats were used to establish an in vivo type 2 diabetes model treated with E2. Rat insulinoma cells (INS-1) were cultured in normal or high glucose media with or without E2. Immunofluorescence double staining was used to detect GPER, GLUT2, insulin, and glucagon immunolocalization in rat islet tissues. Western blot was used to detect GPER, Akt, mTOR, and GLUT2 protein immunocontent. Real-time PCR detected Slc2a2 and glucose kinase (GK) content, and ELISA was used to detect insulin levels. Glucose uptake, GK activity and pyruvate dehydrogenase (PDH) activity were analyzed with glucose detection, GK activity and PDH activity assay kit.

Results: Immunofluorescence double staining confocal indicated that E2 treatment up-regulated expression levels of GPER, GLUT2, and insulin, while down-regulated glucagon. Western blot results revealed E2 increased GPER, Akt/mTOR pathway, and GLUT2 protein immunocontent. Real-time PCR showed E2 elevated Slc2a2, GK content. Moreover, E2 improved insulin secretion, glucose uptake, GK activity, and PDH activity.

Conclusion: Our findings indicated that exogenous E2 up-regulated GPER via the Akt/mTOR pathway to increase GLUT2 protein content and insulin secretion in islet $\beta$ cells.

Keywords: $17 \beta$-estradiol, islet $\beta$ cells, type 2 diabetes mellitus, glucose transporter 2 , insulin secretion

\section{INTRODUCTION}

Type 2 diabetes mellitus (T2DM) is a chronic progressive disease with high morbidity and mortality that are of increasing concern (1). The prevalence of T2DM significantly increases in postmenopausal women (2), which indicates that the prevalence may be related to a decrease of estrogen.

Estrogen, of which the main active form is 17-estradiol (Estrogen 2, E2), primarily originates in the ovary and plays a wide range of physiological roles in the reproductive, cardiovascular, nervous and immune systems via combination with estrogen receptors (3). Previous studies have examined estrogen nuclear receptor $\alpha(E R \alpha)$ and estrogen nuclear receptor $\beta(E R \beta)$ in-depth which 
were found to have an important effect on cell proliferation and apoptosis (4). In recent research, extensive attention has been given to one estrogen membrane receptor called G-coupled estrogen receptor (GPER). GPER is distributed throughout human tissues, especially in rat and mouse islet $\beta$ cells (5). The recent research shows that E2 preserves functional $\beta$-cell mass and affects insulin secretion in islet $\beta$ cells via GPER $(6,7)$. There are also studies which demonstrated E2 and GPER agonist improves insulin secretion on human and mice islets via GPER (8). However, no studies have confirmed whether E2 makes an action in promoting insulin secretion through glucose transporter 2 (GLUT2).

Glucose transporter 2 (GLUT2) is widely distributed in the liver, kidney, intestinal and islet tissues and is an important factor in the regulation of glucose metabolism in islet $\beta$ cells. GLUT2 combines with the glucose kinase (GK) as the glucose receptor on islet $\beta$ cells and increases glucose uptake to promote insulin secretion by sensing hyperglycemia. Pyruvate dehydrogenase (PDH) is a key enzyme in this process.

E2 binds to GPER and affects downstream metabolites through multiple pathways, including the PI3K/Akt pathway (9). Mammalian target of rapamycin (mTOR) is a serine threonine protein kinase with a molecular weight of $289 \mathrm{kd}$, which maintains blood glucose levels by regulating glucose uptake in peripheral tissues such as skeletal muscle and fat (10).

According to this context, we established a T2DM rat model in vivo and cultured high-glucose INS-1 cells in vitro, to detect changes to glucose metabolism and insulin secretion as well as the expression levels of relevant factors employing pretreatment with E2, GPER antagonist (G15), Akt inhibitor (PF 04691502), and mTOR inhibitor (rapamycin) to explore the possible molecular mechanism of GPER via Akt/mTOR pathway in islet $\beta$ cells.

\section{MATERIALS AND METHODS}

\section{Animal Modeling}

Male Sprague-Dawley (SD) rats (5 weeks, SPF grade, 150$180 \mathrm{~g}$, a total of 24 rats) were obtained from Beijing Vital River Laboratory Animal Technology. The rats were fed in an SPF laboratory maintained at $22 \pm 3^{\circ} \mathrm{C}$ at a humidity of $55 \pm 5 \%$ with a cycle $12 \mathrm{~h}$ light $/ 12 \mathrm{~h}$ dark (lights on at 0600 )as well as free access to water and food. All animal experiments were approved by the Institutional Animal Care and Use Committee (IACUC) of China Medical University (Ethic No. 17012).

After adaptive feeding for 7 days, the rats were randomly divided into three groups as follows: (i) The type 2 diabetes mellitus drugs-treatment group (TD group, $n=8$ rats): fed with high-fat, high-sugar diet (20\% protein, $45 \%$ fat, and 35\% carbohydrate, D12451, Beijing Huafu Kang Co., Ltd.) for 8 weeks (11). Rats were then injected intraperitoneally with $20 \mathrm{mg} / \mathrm{kg}$ streptozotocin (STZ, Sigma-Aldrich, Merck KGaA, Germany) Day 1 to Day 3 in the 9th week. STZ dissolves in citric acid and sodium citrate solution (12). Two weeks after STZ injection, E2 (Sigma-Aldrich, Merck KGaA, Germany) was injected intraperitoneally at $10 \mu \mathrm{g} / \mathrm{kg}$ for 8 weeks. E2 dissolves in olive oil. (ii) The type 2 diabetes mellitus group (TM group, $n=8$ rats): the same diet and STZ injection as the TD group. Two weeks after STZ injection, rats were injected with isodose olive oil as an E2 control. The induction success rate for hyperglycemia in both TD and TM groups was 100\% and no rats were lost. (iii) The normal control group (NC group, $n=8$ rats): fed with control $\operatorname{diet}(28 \%$ protein, $12 \%$ fat, and $60 \%$ carbohydrate, Animal Center of China Medical University). Rats were injected with citric, sodium citrate solution, and isodose olive oil as a control for STZ and $\mathrm{E} 2$.

All animals fasted overnight and then took a $2 \mathrm{~g} / \mathrm{kg}$ glucose oral glucose tolerance test (OGTT) and insulin release test, independently, 6 days and 10 weeks after STZ injection (13). The establishment of this model was evaluated by random blood glucose levels of rat tail vein $>16.7 \mathrm{mmol} / \mathrm{L}$ (14) or fasting blood glucose levels $>11.1 \mathrm{mmol} / \mathrm{L}$ (15). The end point of the experiment was a week after the last OGTT. After application of isoflurane anesthesia, the body weight and fat of rats were measured and then islet tissues were collected after cardiac perfusion by cold normal saline and preserved in $4 \%$ paraformaldehyde solution at $4^{\circ} \mathrm{C}$ for immunofluorescence, liquid nitrogen at $-196^{\circ} \mathrm{C}$ for western blot and non-frozen tissue stored in RNA preservation fluid at $-20^{\circ} \mathrm{C}$ for real-time PCR (16).

\section{Cell Culture}

The rat insulinoma cell line (INS-1) was purchased from China Infrastructure of Cell Line Resources (Beijing, China). The cells were concomitantly incubated in RPMI-1640 medium with $10 \%$ fetal bovine serum (FBS, Gibco ${ }^{\mathrm{TM}}$, Thermo Fisher Scientific, USA) and $3.4 \mu \mathrm{l} / \mathrm{L} \beta$-mercaptoethanol (Sigma-Aldrich, Merck $\mathrm{KGaA}$, Germany) in a humidified atmosphere containing 5\% $\mathrm{CO}_{2}$ at $37^{\circ} \mathrm{C}$. After cell density reached $80 \%$ once every 2 days, cells were passaged. After incubation in an FBS-free medium for $24 \mathrm{~h}$ at normal and high glucose with or without E2 and inhibitors, INS-1 cells were divided into the following groups (i) NG: normal glucose ( $5 \mathrm{mmol} / \mathrm{L}$ ) for $24 \mathrm{~h}$, (ii) NE: normal glucose $+0.1 \mu \mathrm{M}$ E2 for $24 \mathrm{~h}$, (iii) NGI: normal glucose $+15 \mu \mathrm{M}$ G15 (Tocris Bioscience Minneapolis, USA) for $24 \mathrm{~h}$, (iv) NAI: normal glucose $+1 \mu \mathrm{M}$ Akt inhibitor (PF-04691502, Selleck Company, USA) for $24 \mathrm{~h}$, (v) NMI: normal glucose $+10 \mu \mathrm{M}$ mTOR inhibitor (rapamycin, Selleck Company, USA) for $48 \mathrm{~h}$, (vi) HG: high glucose (30 mmol/L) for $24 \mathrm{~h}$ (17), (vii) HE: high glucose + $0.1 \mu \mathrm{M}$ E2 for $24 \mathrm{~h}$, (viii) HGI: high glucose $+15 \mu \mathrm{M}$ G15 for $24 \mathrm{~h}$, (ix) HAI: high glucose $+1 \mu \mathrm{M}$ Akt inhibitor for $24 \mathrm{~h}$, (x) HMI: high glucose $+10 \mu \mathrm{M}$ mTOR inhibitor for $48 \mathrm{~h}$ (18).

\section{Immunofluorescence}

In order to study the pancrease morphology, 8 pancreases from each group of rats were removed and weighed, excised fat and lymphatic tissues for serial section for serial section $(19,20)$. $\beta$-cell mass was measured by point-counting stereology according to the previous research (21). After fixing in cold acetone, tissues were incubated with primary antibodies (GPER, ab39742; GLUT2, ab54460, insulin, ab181547; glucagon, ab10988; 1: 200, respectively, Abcam, USA) at $4^{\circ} \mathrm{C}$ overnight. Then tissues were washed and incubated with the secondary antibody (Alexa Fluor ${ }^{\circledR} 488$ Conjugate anti-rabbit $\operatorname{IgG}$ and Alexa Fluor ${ }^{\circledR} 555$ Conjugate anti-rabbit IgG, 1:1,000, \#4412 and 
TABLE 1 | Primer sequences.

\begin{tabular}{|c|c|c|c|c|}
\hline Primers & Genbank accession number & Sequences & Length (bp) & $\operatorname{Tm}\left({ }^{\circ} \mathrm{C}\right)$ \\
\hline Slc2a2-forward & NM_012879 & $5^{\prime}$-CAC CAG CAC ATA CGA CAC CAG AC-3' & 23 & 63.5 \\
\hline Slc2a2-reverse & & 5'-TGG ACA CAG ACA GAG ACC AGA GC-3' & 23 & 63.8 \\
\hline GK-forward & NM_024381 & 5'- GTG AGG CAC GAA GAC CTA GAC AAG-3' & 24 & 62.9 \\
\hline GK-reverse & & $5^{\prime}$ - TCA CCA TTG CCA CAT CCA TC-3' & 20 & 58.2 \\
\hline$\beta$-actin-forward & NM_031144 & 5'-CAC TAT CGG CAA TGA GCG GTT CC-3' & 23 & 64.0 \\
\hline$\beta$-actin-reverse & & 5'-CAG CAC TGT GTT GGC ATA GAG GTC-3' & 24 & 63.7 \\
\hline
\end{tabular}

\#4413, Cell Signaling Technology, USA) at room temperature for $1 \mathrm{~h}$. Sections were washed again and then DAPI stained (\#4083, Cell Signaling Technology, USA) at room temperature for $10 \mathrm{~min}$. Images of the sections were taken under an Olympus fluorescence confocal microscope (FV-1000, Japan).

\section{Western Blot}

Islets were isolated with collagenase (C0130 Sigma-Aldrich, Merck KGaA, Germany) as described in previous literature $(22,23)$. Rat islet tissues and cell samples were extracted with lysis buffer (P0013B, Beyotime Biotechnology, China) containing $1 \%$ Triton X-100, 1\% deoxycholate, $0.1 \%$ SDS, phosphatase Inhibitor cocktail and protease Inhibitor cocktail (78420 and 78429, Thermo Fisher Scientific, USA). After centrifugation at $16,000 \times \mathrm{g}$ for $20 \mathrm{~min}$, a BCA protein assay kit (P0010S, Beyotime Biotechnology, China) was used to measure protein concentration. Protein bands were separated by $6 \%$ and $10 \%$ SDS-PAGE electrophoresis and then transferred onto PVDF membranes $(0.45 \mathrm{~mm}$, Millipore, USA) for $1 \mathrm{~h}$ to detect GPER, p-Akt, t-Akt, GLUT2 and $\beta$-actin, as well as $3 \mathrm{~h}$ for $\mathrm{p}$-mTOR and $t$-mTOR. The membranes were cut based on the molecular weight of target proteins after transfer and then blocked with $5 \%$ BSA for $1 \mathrm{~h}$. Membranes were incubated with primary antibodies (GPER, SAB2107697; GLUT2, AV41706; $\beta$-actin, SAB2100037; 1:1,000, respectively, Sigma-Aldrich, Merck KGaA, Germany; p-Akt, \#5012; t-Akt, \#4691; p-mTOR, \#5536; t-mTOR, \#2983; 1:1,000, respectively, Cell Signaling Technology, USA) at $4^{\circ} \mathrm{C}$ overnight, and then secondary antibody (Anti-rabbit IgGHRP, 1:2,000, \#7074, Cell Signaling Technology, USA) at room temperature for $2 \mathrm{~h}$ after washed 3 times. Protein bands were measured with Pierce ${ }^{\mathrm{TM}}$ ECL Plus Substrate (32109, Thermo Fisher Scientific, USA) in the MicroChemi 4.2 system (Jerusalem, Israel). Based on the similar molecular weight of target proteins, the primary and secondary antibodies were removed by stripping buffer (P0025N, Beyotime Biotechnology, China) and then the membranes were blocked and the antibodies were incubated for subsequent experiments.

\section{Real-time PCR}

Total RNAs were extracted with TRIzol reagent (Invitrogen, Thermo Fisher Scientific, USA) according to the manufacturer's instructions. Primer sequences were shown in Table 1 (Sangon Biotech, China). PrimeScript ${ }^{\mathrm{TM}}$ RT Reagent Kit with gDNA Eraser (Perfect Real Time), TB Green ${ }^{\mathrm{TM}}$ Premix Ex Taq ${ }^{\mathrm{TM}}$ II (Tli RNase H Plus) and the Thermal Cycler Dice Real-time PCR system (TaKaRa, Japan) of 1,000 ng total RNA were used for each reaction.

\section{Measurement of Glucose Uptake}

Glucose uptake was determined by a glucose uptake colorimetric assay kit (ab136955, Abcam, Cambridge, MA, USA) according to the manufacturer's instruction. Briefly, INS-1 cells were starved in a 96-well plate with FBS-free 1640 medium overnight and then incubated with Krebs-Ringer-Phosphate-Hepes (KRPH) buffer $\left(20 \mathrm{mM}\right.$ HEPES, $5 \mathrm{mM} \mathrm{KH} \mathrm{PO}_{4}, 1 \mathrm{mM} \mathrm{MgSO}, 1 \mathrm{mM}$ $\mathrm{CaCl}_{2}, 136 \mathrm{mM} \mathrm{NaCl}, 4.7 \mathrm{mM} \mathrm{KCl}, \mathrm{pH}$ 7.4) containing 2\% BSA for $40 \mathrm{~min}$. Then cells were, respectively, incubated in normal or high glucose medium and pre-treated in different groups (no treatment, $0.1 \mu \mathrm{M}$ E2 for $30 \mathrm{~min}, 15 \mu \mathrm{M}$ G15 for $30 \mathrm{~min}$, $1 \mu \mathrm{M}$ PF-04691502 for $30 \mathrm{~min}$ and $10 \mu \mathrm{M}$ rapamycin for $1 \mathrm{~h}$ ). Finally, $10 \mu \mathrm{l}$ of 2-deoxy-glucose (2-DG) was added for a $20 \mathrm{~min}$ incubation, then the substrate oxidation reaction was detected by OD at wavelength $412 \mathrm{~nm}$.

\section{Glucokinase Activity and Insulin Secretion}

INS-1 cells cultured in normal or high glucose medium were pretreated with either no treatment, $0.1 \mu \mathrm{M}$ E2 for $30 \mathrm{~min}$, $15 \mu \mathrm{M}$ G15 for $30 \mathrm{~min}, 1 \mu \mathrm{M}$ PF-04691502 for $30 \mathrm{~min}$ or $10 \mu \mathrm{M}$ rapamycin for $1 \mathrm{~h}$, under the same concentration as the measurement of glucose uptake. GK activity was determined by the rat glucokinase enzyme linked immunosorbent assay (ELISA) kit (SEA667Ra, Cloud-Clone Corp., USA). Serum samples collected by insulin release testing after STZ injection 2 and 10 weeks and cell supernatant after $24 \mathrm{~h}$ incubated with normal or high glucose were analyzed with the rat insulin ELISA kit (CEA448Ra, Cloud-Clone Corp., USA). OD 450 value was measured with Power Wave XS (Biotek, USA).

\section{Pyruvate Dehydrogenase Activity}

INS-1 cells cultured in normal or high glucose medium were pretreated with either no treatment or $0.1 \mu \mathrm{M}$ E2 for $30 \mathrm{~min}$, $\mathrm{PDH}$ activity was measured by a Pyruvate Dehydrogenase (PDH) Enzyme Activity Microplate Assay Kit (ab109902, Abcam, USA).

\section{Statistical Analysis}

All measurements were repeated three times. Results were expressed as the mean \pm standard deviation. Comparison of means was completed with one-way ANOVA after the data were submitted to normality and homoscedasticity tests. $P<0.05$ was considered to be statistically significant. Statistical analysis was performed using SPSS 22.0 statistical software (SPSS Inc., USA). 


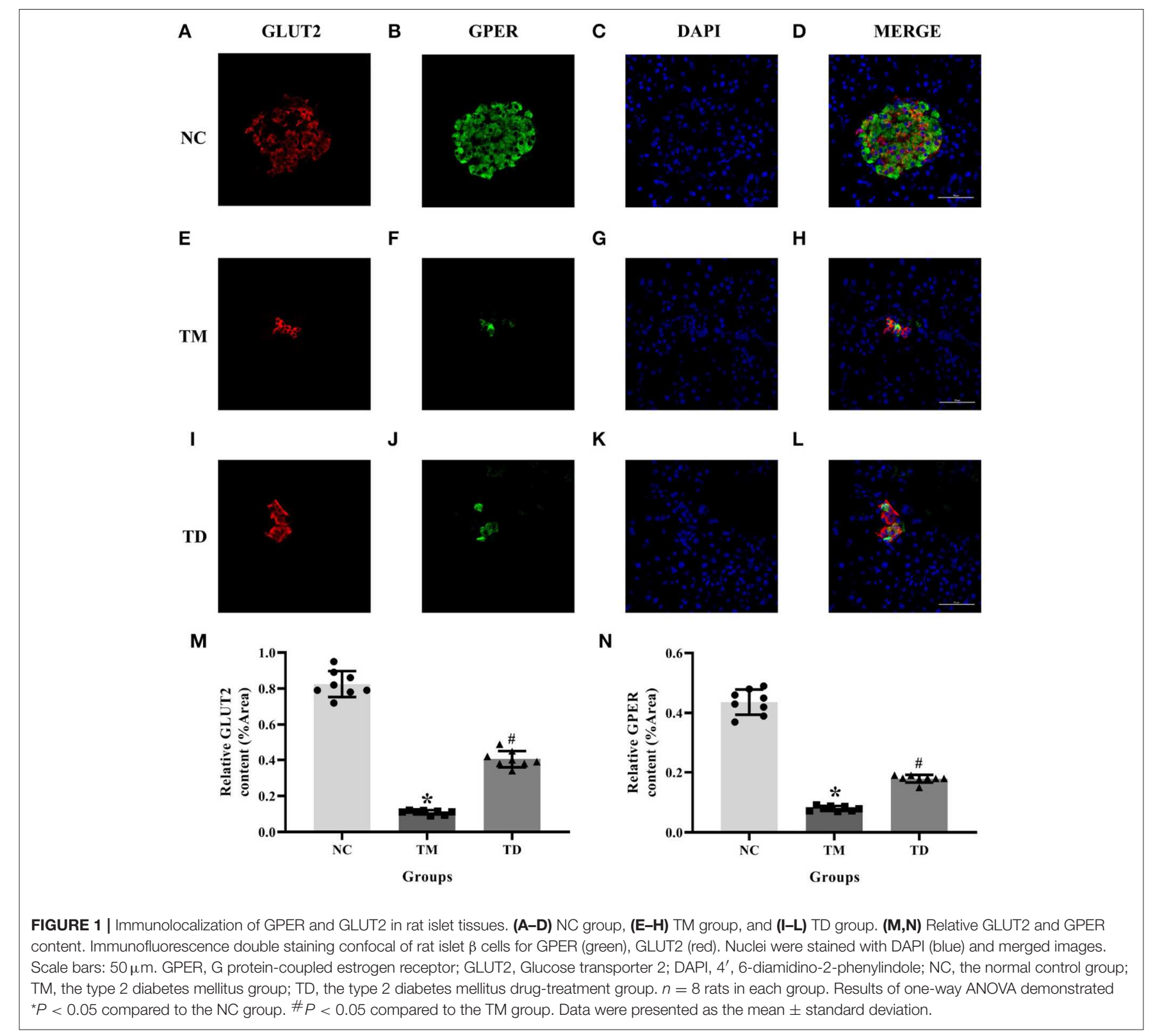

\section{RESULTS}

\section{Immunolocalization of GPER and GLUT2 in Rat Islet Tissues}

We adopted immunofluorescence double staining confocal detection to explore the immunolocalization levels of GPER and GLUT2 in rat islet tissues. Our results showed that the immunolocalization levels of GPER and GLUT2 in rat islet tissues were significantly more decreased in the TM group than those of the NC group. Moreover, the immunolocalization levels of GPER and GLUT2 in the TD group were significantly increased compared with the TM group $(P<0.05)$, as shown in Figure 1.

\section{Immunolocalization of Insulin and Glucagon in Rat Islet Tissues}

Serial sections immunofluorescence double staining was applied to immunolocalize insulin and glucagon in rat islet tissues. Results indicated that the immunolocalization level of insulin was much more declined in the TM group than that of the NC group. Moreover, the immunolocalization level of insulin in the TD group was more obviously elevated than that of the TM group. The immunolocalization level of glucagon was more elevated in the TM group than that of the NC group and declined in the TD group compared with the TM group $(P<0.05)$, as shown in Figure 2. 


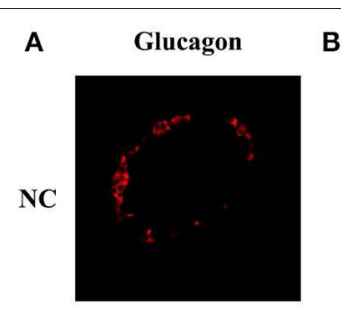

E

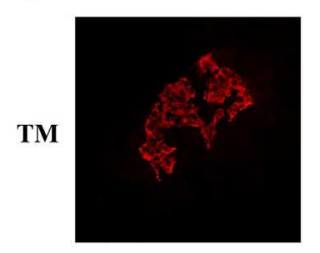

I

TD

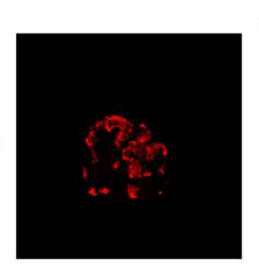

M
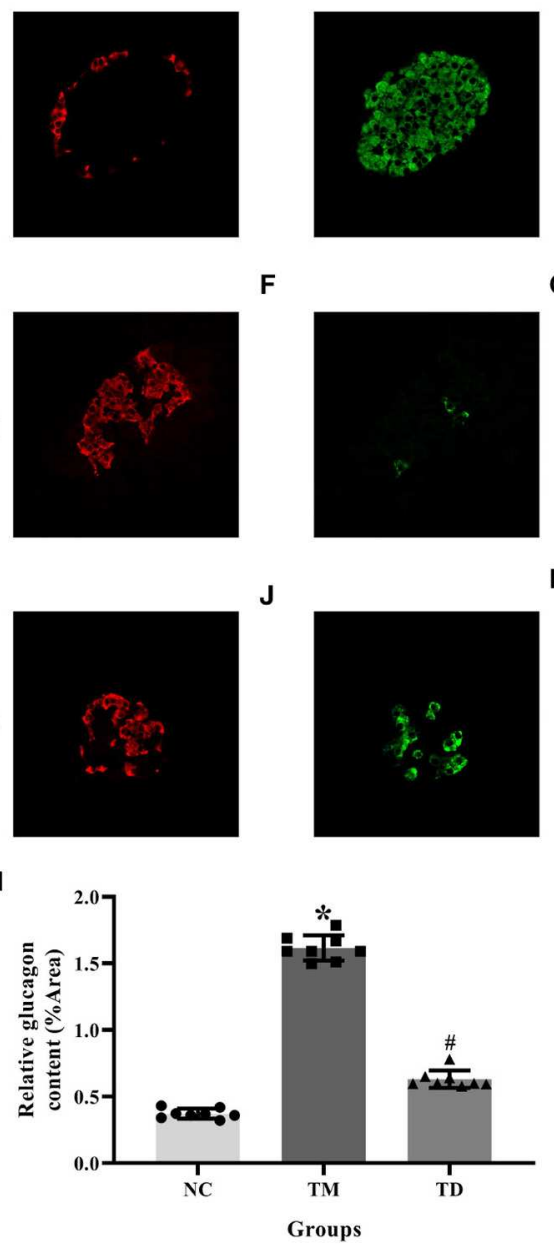

F

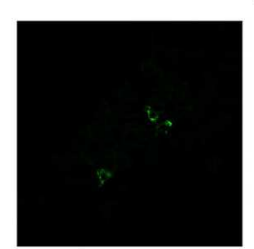

J

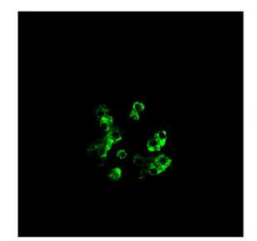

C

$\mathbf{N}$

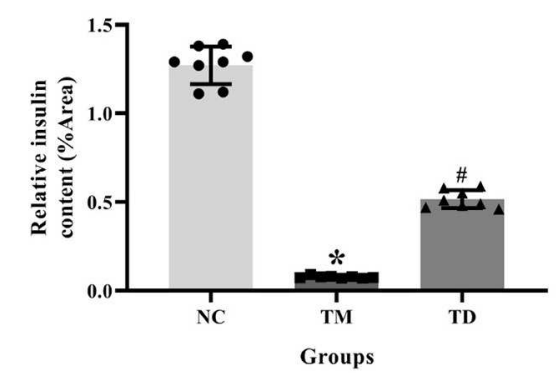

FIGURE 2 | Immunolocalization of insulin and glucagon in rat islet tissues. (A-D) NC group; (E-H) TM group; and (I-L) TD group. (M,N) Relative GLUT2 and GPER content. Immunofluorescence double staining confocal of rat islet $\beta$ cells for glucagon (red), insulin (green). Nuclei were stained with DAPI (blue) and merged images. Scale bars: $50 \mu \mathrm{m}$. DAPI, 4', 6-diamidino-2-phenylindole; NC, the normal control group; TM, the type 2 diabetes mellitus group; TD, the type 2 diabetes mellitus drug-treatment group. $n=8$ rats in each group. Results of one-way ANOVA demonstrated ${ }^{*} P<0.05$ compared to the NC group. \# $P<0.05$ compared to the TM group. Data were presented as the mean \pm standard deviation.

\section{Effects of E2 on Physiological Indexes and Biofactors in Rats}

OGTT showed that glucose levels in the TM groups at $6 \mathrm{~d}$ and 10w had more significant rises compared with the NC group. Moreover, glucose levels in the TM 10w group were higher than that of TM $6 \mathrm{~d}$ and TD groups. The insulin levels in TM $6 \mathrm{~d}$ were elevated, while reduced in TM10w compared with the NC group. The insulin levels in the TD group were more higher than that of the TM 10w group $(P<0.05)$.

The contents of Slc2a 2 and GK mRNA, and the protein of GPER and GLUT2 in rat islet tissues were detected by real-time PCR and western blot. The contents of Slc2a2, GK mRNA and GPER, GLUT2 protein were reduced in the TM group, while they were elevated in the TD group $(P<0.05)$.
Body weight and body fat ratios were evidently declined in the TM group than those in the NC group. However, they were risen in the TM group than those in the TD group $(P<0.05$; Figure 3$)$.

\section{Glucose Metabolism and Insulin Secretion in INS-1 Cells}

Glucose uptake, GK activity, PDH activity and insulin secretion were measured to explore glucose metabolism in INS-1 cells cultured in normal or high glucose medium and pretreated respectively with or without E2, G15, PF-04691502 and rapamycin. Glucose uptake, GK activity, $\mathrm{PDH}$ activity and insulin secretion were reduced in the $\mathrm{HG}$ group compared with the NG group. It was clear that E2 increased glucose uptake, GK activity, PDH activity and insulin secretion while G15, 
A

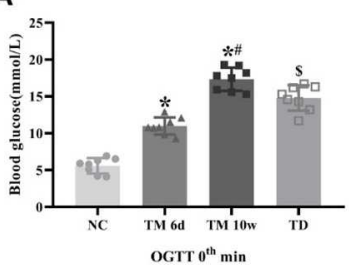

D
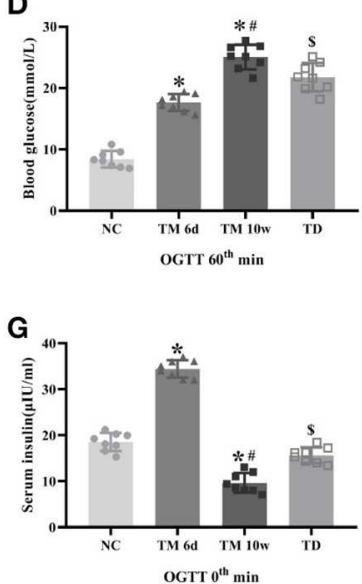

J

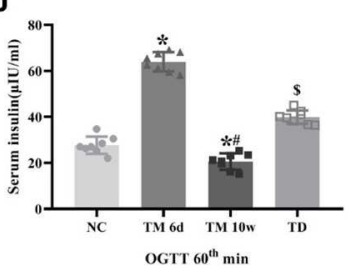

M

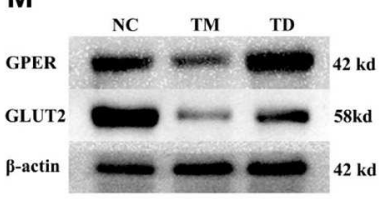

P

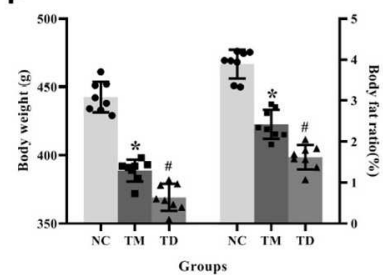

B

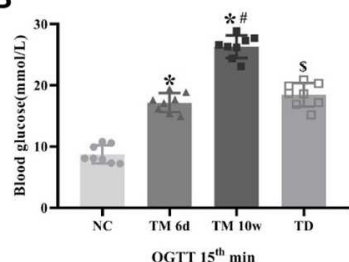

E

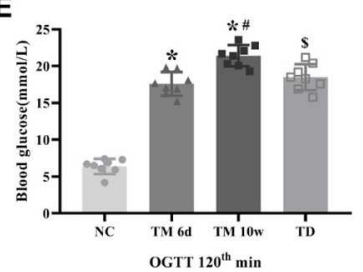

H

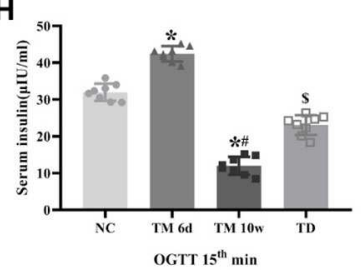

K

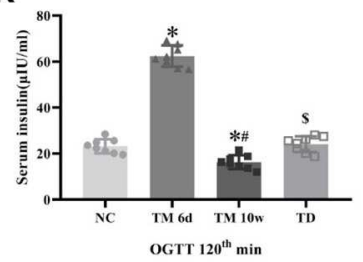

N

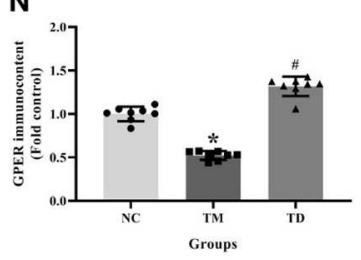

Q

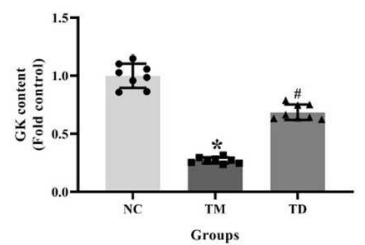

C

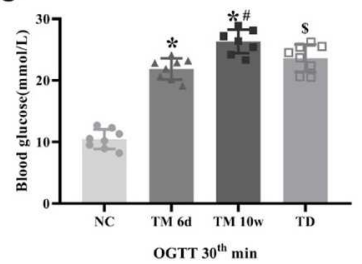

F

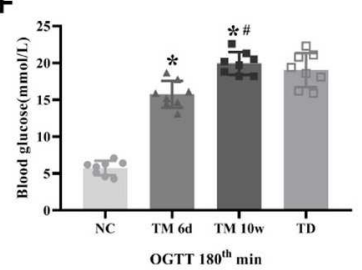

I

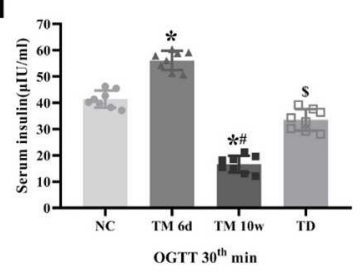

L

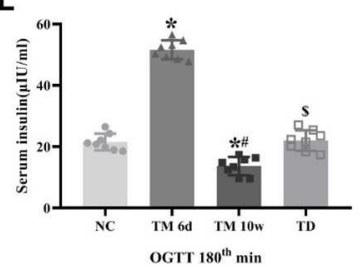

0

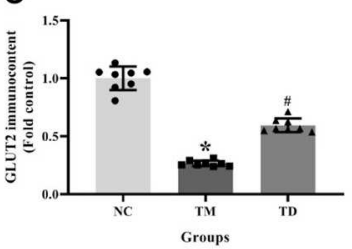

$\mathbf{R}$

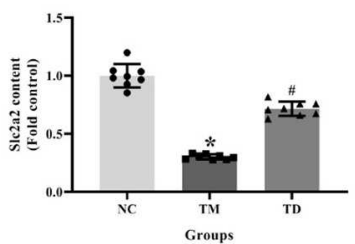

FIGURE 3 | Effects of E2 on physiological indexes and biofactors in rats. (A-L) Blood glucose and insulin levels at different time point in OGTT. (M) Protein bands. $(\mathbf{N}, \mathbf{O})$ GPER and GLUT2 immunocontents, normalized to the internal control ( $\beta$-actin). (P) Body weight and body fat ratios. (Q,R) Slc2a2 and GK contents. NC, the normal control group; TM 6d, the type 2 diabetes mellitus group 2 weeks after STZ injection; TM 10w, the type 2 diabetes mellitus group 10 weeks after STZ injection; TD, the type 2 diabetes mellitus drug-treatment group. (A-L,P) $n=8$ rats in each group. (M-O,Q,R). $n=8$ rats in each group. $n=$ randomly $3 / 8$ rats in each group. Results of one-way ANOVA demonstrated ${ }^{*} P<0.05$ compared to the NC group. $\# P<0.05$ compared to the TM 6 d or TM groups. $\$ P<0.05$ compared to the TM 10w group. Data were presented as the mean \pm standard deviation. 
PF-04691502, and rapamycin decreased these functions in both cultures $(P<0.05$; Figure 4$)$.

\section{SIc2a2 and GK Content in INS-1 Cells}

Real-time PCR was employed to explore Slc2a2 and GK mRNA contents cultured in normal or high glucose medium and pretreated, respectively, with E2, G15, PF-04691502, and rapamycin. Slc2a2 and GK mRNA contents were declined in the HG group compared with the NG group. It was observed that E2 increased Slc2a2 and GK mRNA content while G15, PF-04691502 and rapamycin decreased these mRNA content in both cultures $(P<0.05$; Figure 5).

\section{Protein Immunocontent in Normal and High Glucose Cultured INS-1 Cells}

Western blot was used to detect GPER, p-Akt/t-Akt, p-mTOR/tmTOR, and GLUT2 protein immunocontents from cells cultured in normal or high glucose medium. It was evident that compared with the NG group, the GPER, p-Akt/t-Akt, p-mTOR/t- mTOR, and GLUT2 protein immunocontents were reduced in the HG group while increased in the NE group. Moreover, the protein immunocontents were elevated in the HE group than that of the HG group $(P<0.05$; Figure 6).

\section{Protein Immunocontent in Normal Glucose Cultured INS-1 Cells With Different Treatment}

In order to explore whether E2 influences GLUT2 protein content through Akt/mTOR pathway in normal or high glucose medium, western blot was applied to detect GPER, p-Akt/tAkt, p-mTOR/t-mTOR, and GLUT2 protein immunocontents pretreated with E2, G15, PF-04691502, and rapamycin. E2 treatment was found to enhance GPER, p-Akt/t-Akt, pmTOR/t-mTOR, and GLUT2 protein immunocontents while G15 suppressed such concentrations compared with the NG group $(P<0.05)$. It was observed that PF-04691502 inhibited p-Akt/t-Akt, p-mTOR/t-mTOR, and GLUT2 immunocontents $(P<0.05)$, however, it had no significant impact on GPER protein immunocontent $(P>0.05)$. Somewhat similarly, rapamycin inhibited $\mathrm{p}$-mTOR/t-mTOR and GLUT2 content $(P<0.05)$, while it had no distinct effect on GPER and p-Akt/tAkt protein content $(P>0.05$; Figures 7,8$)$.

\section{DISCUSSION}

The incidence of type 2 diabetes mellitus (T2DM) has been increasing globally as a result of a combination of genetic and environmental factors (24). This disease has an insidious onset, longer duration, increasing rates of mortality and disability; it's mostly in adults, which draws much attention (25). The main pathophysiological changes associated with T2DM are $\beta$ cell dysfunction and insulin resistance, while glucose metabolic disorders, elevated blood glucose levels, and damage to multiple organ systems are the main manifestations $(26,27)$. The pathogenesis of T2DM has not been fully elucidated. However, it has been reported that the abnormal structure and function of islet $\beta$ cells has a close connection with the pathogenesis of T2DM $(28,29)$. Any breakdown of this pathogenetic chain can lead to the occurrence of the disease from the synthesis and secretion of insulin by islet $\beta$ cells to the biological effects of binding of insulin to specific receptors (30).

Based on the above literature, we established a T2DM rat model in vivo in order to simulate type 2 diabetes pathogenesis in humans with a high-fat and high-glucose diet resulting in obesity, insulin resistance as well as STZ injection which may lose the compensation of islet $\beta$ cells. The results of blood glucose, insulin levels and body fat ratio were constant with the T2DM patients reported in the literature (31). Previous literatures showed that body fat ratio were reduced and abnormal insulin secretion were improved in female SD rats treated with E2 after ovary resection operation (32), consistent with male SD rats in our results.

GLUT2 is required in response to glucose stimulation by islet $\beta$ cells and is widely expressed in liver cells, islet cells, and epithelial cells with the absorption function of the small intestine and kidney (33). GLUT2 is one of the most important glucose transporters, whose function has been observed to be damaged and down-regulated expression among T2DM patients (34). Similarly, GK is a kind of hexokinase, which mainly exists in mature liver cells and islet $\beta$ cells (35). GLUT2 acts as a glucose sensor in islet $\beta$ cells along with GK to increase the intake of glucose for elevated blood glucose (36, 37). It also improves the activity of GK, while GK catalyzes glucose into glucose 6-phosphate to promote glycolysis, $\mathrm{PDH}$ activity, and the tricarboxylic acid cycle (38). This increases ATP formation, which leads to the closure of ATP-sensitive potassium channels, and the depolarization of the cell membrane as well as the internal flow of calcium ion, thus promoting insulin secretion (39).

Our research showed that Slc2a2, GK content and GLUT2 protein in the TM group was down-regulated, indicating that GLUT2 glucose transport and metabolic functions were damaged in T2DM rats, which is demonstrated in the supplemental results. INS-1 cells were cultured with normal and high glucose medium in vitro, and relevant tests were performed to explore the consistency of the subsequent results both in vivo and in vitro.

Our results showed that a high-glucose environment inhibited glucose uptake rates, GK activities and insulin secretion as well as Slc2a2, GK content, and GLUT2 protein, are consistent with our results in vivo. This finding indicates that hyperglycemia inhibits the GLUT2 perception, reduces glucose uptake and transport, as well as inhibits GK, PDH activity at the same time, which leads to a down-regulation of glucose uptake rate, obstructs glucose metabolism, therefore results in insufficient insulin secretion and further elevation of blood glucose.

PI3K/Akt signaling pathway was shown to be the key to obesity-induced insulin resistance and T2DM (40). Mammal rapamycin target protein (mTOR) is the downstream product of this signaling pathway, functioning as part of cell growth regulation and response to the cell nutrition state (41). Moreover, PI3K/Akt can affect islet $\beta$ cell metabolism and apoptosis by regulating insulin-related signaling pathways, thus affecting insulin secretion and blood glucose regulation, which may play an important role in maintaining body metabolic homeostasis 
A

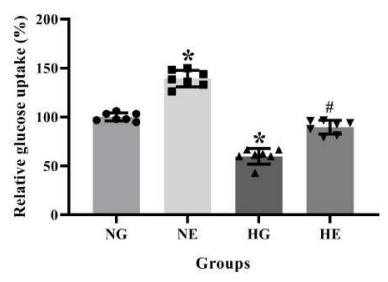

D

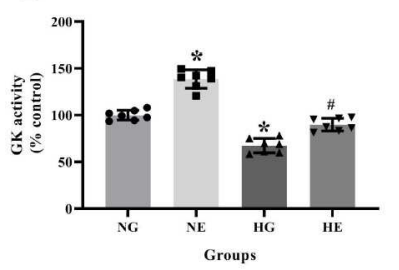

G

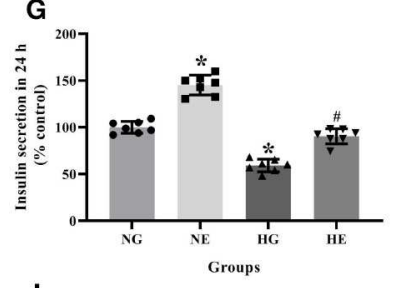

J

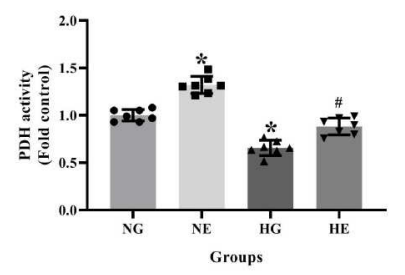

B

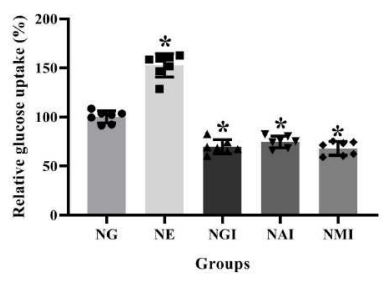

E

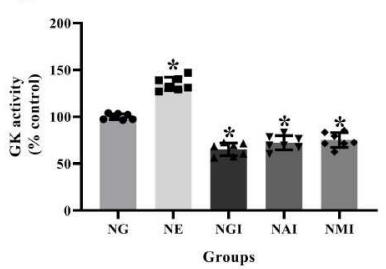

H

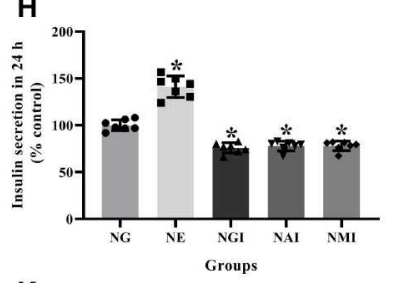

K

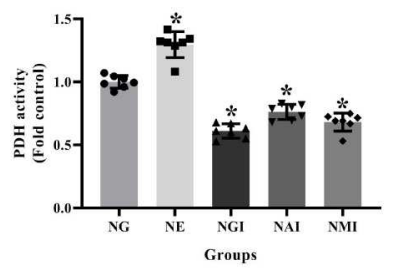

C

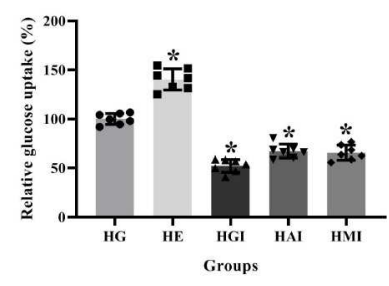

F
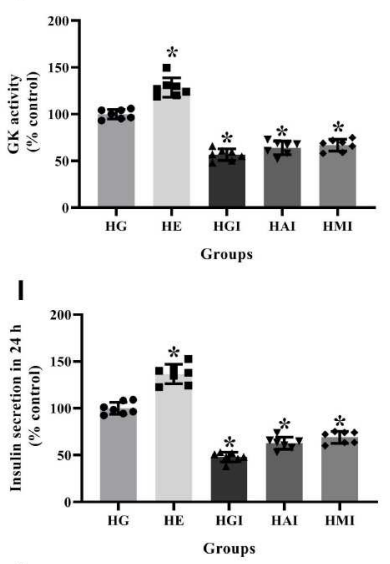

L

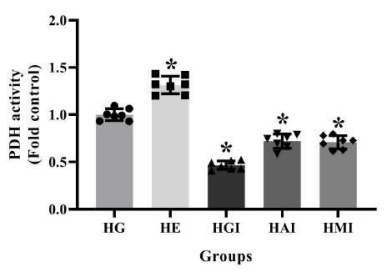

FIGURE 4 | Glucose metabolism and insulin secretion in INS-1 cells. Glucose uptake in (A) NG and HG groups with or without E2 treatment, (B) NG groups with different treatment, and (C) HG groups with different treatment. GK activity in (D) NG and HG groups with or without E2 treatment, (E) NG groups with different treatment and (F) HG groups with different treatment. Twenty four hours insulin secretion in (G) NG and HG groups with or without E2 treatment, (H) NG groups with different treatment and (I) in HG groups with different treatment. PDH activity in (J) NG and HG groups with or without E2 treatment, (K) NG groups with different treatment and (L) HG groups with different treatment. NG, normal glucose; NE, normal glucose + E2; NGl, normal glucose + GPER antagonist; NAl, normal glucose + Akt inhibitor; NMl, normal glucose + mTOR inhibitor; HG, high glucose; HE, high glucose + E2; HGl, high glucose + GPER antagonist; HAl, high glucose + Akt inhibitor; HMI, high glucose + mTOR inhibitor. $n=7$ in each group. Results of one-way ANOVA demonstrated ${ }^{*} P<0.05$ compared to the NG or HG group.

$\# P<0.05$ compared to the $H G$ group. Data were presented as the mean \pm standard deviation.

(42). To investigate the relationship between PI3K/Akt pathway and GLUT2-induced glucose metabolism, INS-1 cells cultured with normal glucose and high glucose were pretreated with Akt and mTOR inhibitors (PF-04691502, rapamycin), respectively. Furthermore, our results showed that high glucose inhibits the relative expression levels of $\mathrm{p}$-Akt/t-Akt and $\mathrm{p}$-mTOR/tmTOR. Akt and mTOR inhibitors inhibited glucose uptake, GK activity and insulin secretion. A high glucose environment down-regulated the relative expression of GLUT2, GK mRNA, p-mTOR/t-mTOR and GLUT2 proteins in high and normal glucose cultured INS-1 cells. However, the relative expression of p-Akt/t-Akt was inhibited by Akt inhibitors rather than by mTOR inhibitors suggesting that high glucose down-regulates the expression of Akt/mTOR pathway. Moreover, Akt can regulate the expression of mTOR, affecting glucose transport uptake and insulin secretion in INS-1 cells cultured with both normal and high glucose.

Estrogen, whose most active form is E2, is a steroid hormone which mainly acts by combination with estrogen receptors (43). Previous literature has shown that the incidence of T2DM in postmenopausal women is significantly increased compared with premenopausal individuals (44). This suggests that a decrease in estrogen may be associated with the occurrence and development of T2DM. The classical estrogen receptors (ER) are nuclear estrogen receptor, including $\mathrm{ER} \alpha$ and $\mathrm{ER} \beta$, which participate in the regulation of enormous complex physiological processes in humans (45). GPER is one of the membranebound estrogen receptors with rapid action and independence 


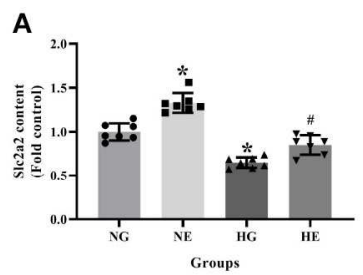

D

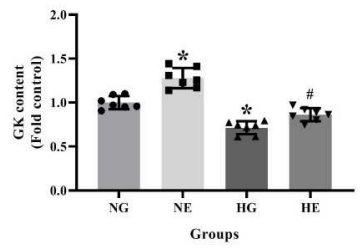

B

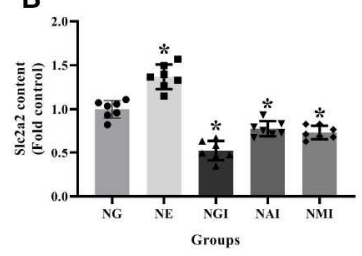

E

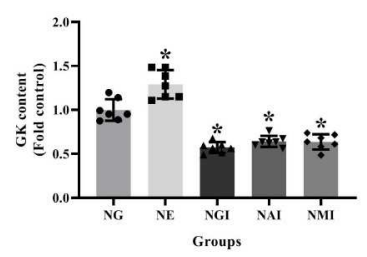

C

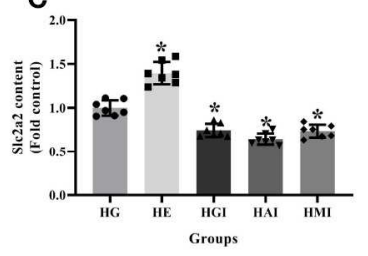

F

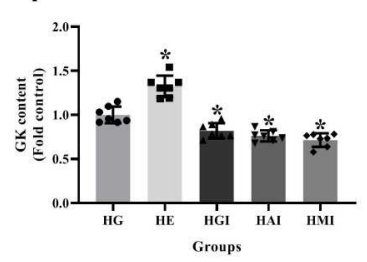

FIGURE 5 | Slc2a2 and GK content in INS-1 cells. Slc2a2 content in (A) NG and HG groups with or without E2 treatment, (B) NG groups with different treatment and (C) HG groups with different treatment. GK content in (D) NG and HG groups with or without E2 treatment, (E) NG groups with different treatment, and (F) HG groups with different treatment. NG, normal glucose; NE, normal glucose + E2; NGl, normal glucose + GPER antagonist; NAl, normal glucose + Akt inhibitor; NMI, normal glucose + mTOR inhibitor; HG, high glucose; HE, high glucose + E2; HGl, high glucose + GPER antagonist; HAl, high glucose + Akt inhibitor; HMI, high glucose + mTOR inhibitor. $n=7$ in each group. Results of one-way ANOVA demonstrated ${ }^{*} P<0.05$ compared to the NG group. ${ }^{\#} P<0.05$ compared to the HG group. Data were presented as the mean \pm standard deviation.

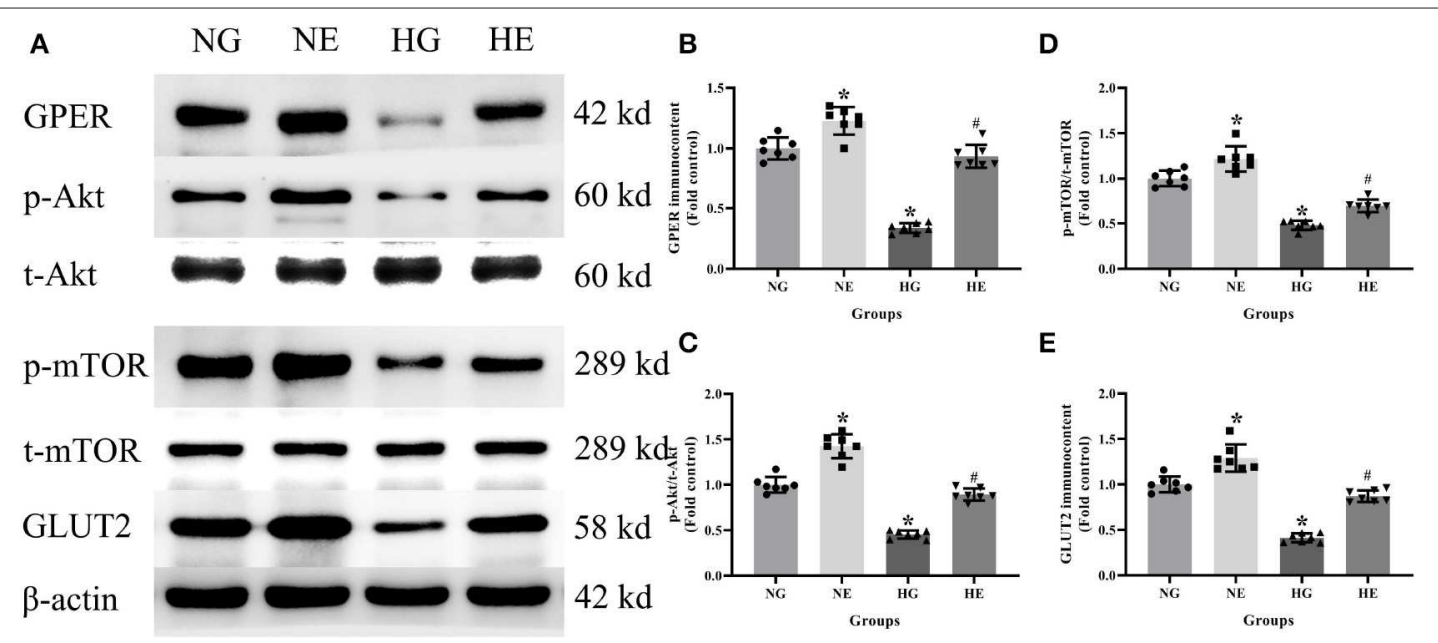

FIGURE 6 | Protein immunocontent in normal and high glucose cultured INS-1 cells with or without E2 treatment. (A) Protein bands; (B) GPER immunocontent, normalized to the internal control ( $\beta$-actin); (C) p-Akt/t-Akt; (D) p-mTOR/t-mTOR; and (E) GLUT2 immunocontent, normalized to the internal control ( $\beta$-actin). NG, normal glucose; HG, high glucose; NE, normal glucose pre-treated with E2; HE, high glucose pre-treated with E2. $n=7$ in each group. Results of one-way ANOVA demonstrated ${ }^{*} P<0.05$ compared to the NG group. $\# P<0.05$ compared to the $\mathrm{HG}$ group. Data were presented as the mean \pm standard deviation.

on gene regulation (46). Previous studies have indicated that E2 plays a neuroprotective role in activating ER and improving the efficiency of glucose transporters (47). Estrogen can also regulate glycolysis by promoting the expression of key enzymes in glycolysis, thus interfering glucose metabolism in tumor cells (48). Moreover, studies have suggested that GPER, widely distributed in a variety of tissues, including cytomembrane of islet $\beta$ cells, both in rats and mice, can interact with the epidermal growth factor receptor (EGFR) -related signaling pathway and crosstalk with multiple other signaling pathways (49).

In order to explore whether E2 regulates glucose metabolism and insulin secretion via GPER and Akt/mTOR pathway, T2DM rats were treated with E2 and INS-1 cells in normal and high glucose cultures pretreated with E2 and G15, respectively. The previous studies showed that E2 promoted insulin secretion and reduced blood glucose levels in T2DM mice (8), and that E2 reduced glucagon and increased glucagon-like peptide for the balance of glucostasis (50). Besides, other studies indicated that E2 increases insulin and decreases glucagon in human pancreatic islets (6), consistent with our present study. In this study E2 was confirmed to increase insulin secretion and improve glucose metabolism, consistent with previous studies on the benefits of improvement on glucose metabolism treated with insulin (51). However, there is no literature supporting the E2 benefits 


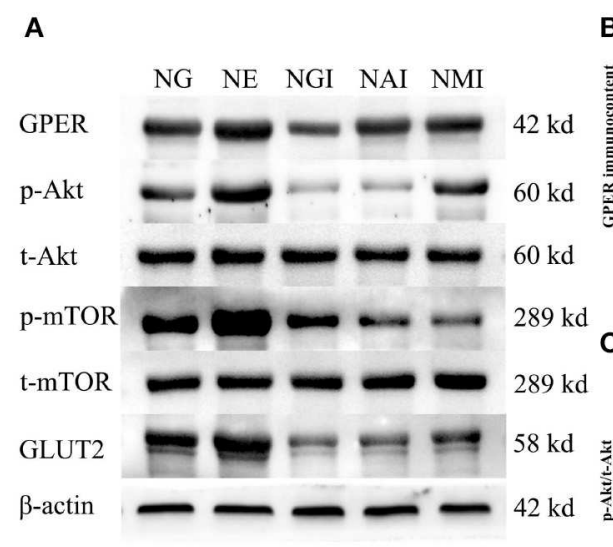

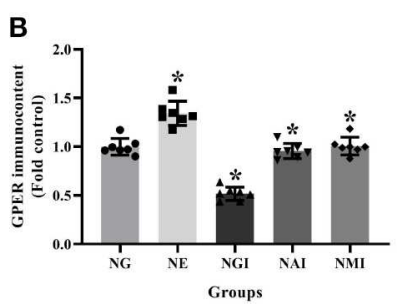

c

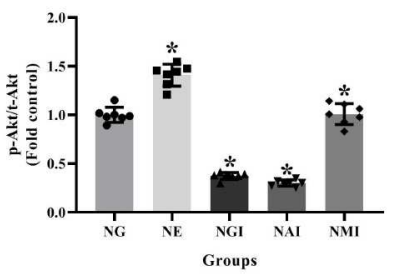

D

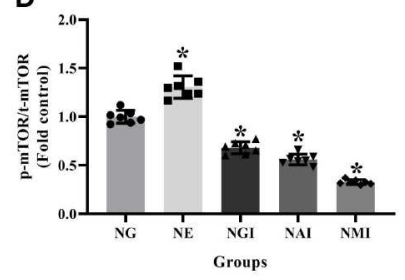

E

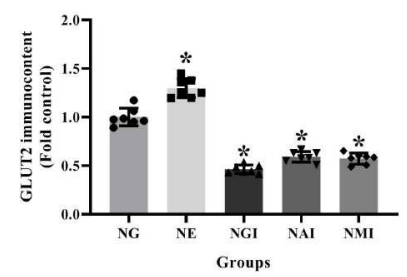

FIGURE 7 | Protein immunocontent in normal glucose cultured INS-1 cells with different treatment. (A) Protein bands; (B) GPER immunocontent, normalized to the internal control ( $\beta$-actin); (C) p-Akt/t-Akt; (D) p-mTOR/t-mTOR; and (E) GLUT2 immunocontent in NG groups with different treatment, normalized to the internal control ( $\beta$-actin). NG, normal glucose; NE, normal glucose + E2; NGl, normal glucose + GPER antagonist; NAl, normal glucose + Akt inhibitor; NMI, normal glucose + mTOR inhibitor. $n=7$ in each group. Results of one-way ANOVA demonstrated ${ }^{*} P<0.05$ compared to the NG group. Data were presented as the mean \pm standard deviation.

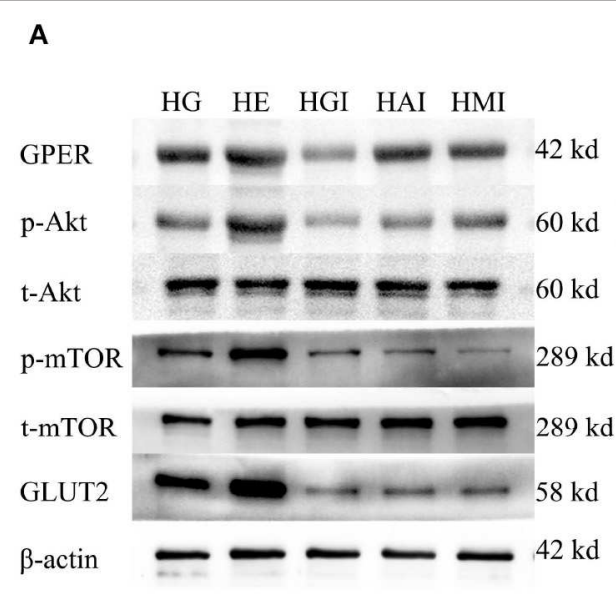

B

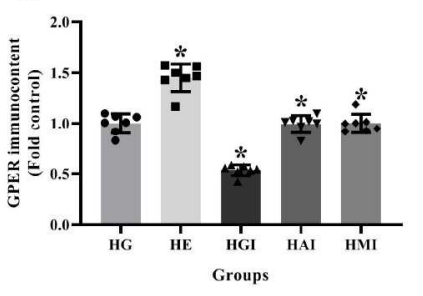

C

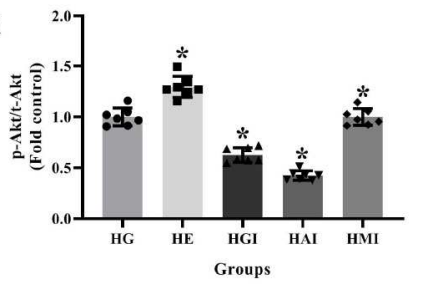

D

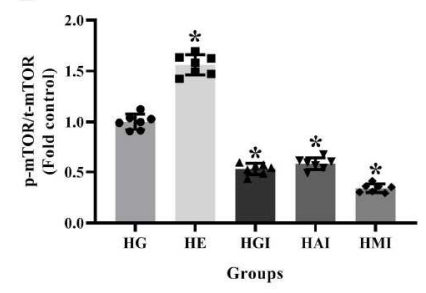

E

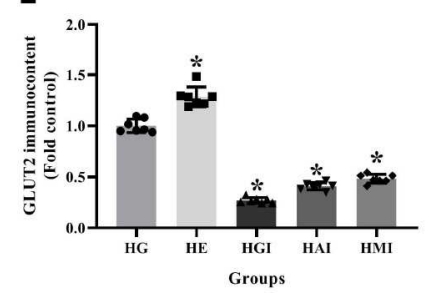

FIGURE 8 | Protein immunocontent from INS-1 cells cultured in high glucose with different treatments. (A) Protein bands; (B) GPER content, normalized to the internal control ( $\beta$-actin); (C) p-Akt/t-Akt; (D) p-mTOR/t-mTOR; and (E) GLUT2 immunocontent in HG groups with different treatments, normalized to the internal control ( $\beta$-actin). HG, high glucose; HE, high glucose + E2; HGl, high glucose + GPER antagonist; HAl, high glucose + Akt inhibitor; HMl, high glucose + mTOR inhibitor. $n=7$ in each group. Results of one-way ANOVA demonstrated ${ }^{*} P<0.05$ compared to the HG group. Data were presented as the mean \pm standard deviation.

instead of insulin therapy considering the possible side effects of E2 therapy in large samples of people (52). It will be an interesting topic on how to avoid the side effects of E2 in type 2 diabetes patients.

E2 was observed to up-regulate the content of Slc2a2 and GK, as well as elevate the levels of GPER and GLUT2 protein in INS-1 cells and TD group rats, which suggests that GPER is expressed in rat islet $\beta$ cells and E2 can improve glucose metabolism and promote insulin secretion via GPER. The results of in vitro experiment showed that E2 increased glucose uptake, GK activity,
$\mathrm{PDH}$ activity and insulin secretion and also up- regulated the relative expression of Slc2a2, GK content, GPER, p-Akt/t-Akt, p$\mathrm{mTOR} / \mathrm{t}-\mathrm{mTOR}$, and GLUT2 protein in normal and high-glucose cultures. In contrast, the G15 group was observed to have the opposite effect. These findings indicated that $\mathrm{E} 2$ can regulate the Akt/mTOR pathway by GPER to improve glucose metabolism and insulin secretion.

In sum, the treatment of T2DM with E2 improved glucose metabolism and insulin secretion via GPER. Further exogenous E2 eased glucose metabolism dysfunction in high-glucose 
cultured INS-1 cells through GPER and Akt/mTOR pathway, while G15 demonstrated the opposite effect. These results suggested that E2 can improve glucose metabolism and insulin secretion of islet $\beta$ cells through GPER via Akt/mTOR pathway. These findings may provide a new theoretical basis for the treatment of T2DM.

\section{DATA AVAILABILITY}

The datasets generated for this study are available on request to the corresponding author.

\section{ETHICS STATEMENT}

The procedures for care and use of animals were approved by the Institutional Animal Care and Use Committee (IACUC) of the First Affiliated Hospital of China Medical University

\section{REFERENCES}

1. Petersen MC, Shulman GI. Mechanisms of insulin action and insulin resistance. Physiol Rev. (2018) 98:2133-223. doi: 10.1152/physrev.00063.2017

2. Mascarenhas-Melo F, Marado D, Palavra F, Sereno J, Coelho Á, Pinto $\mathrm{R}$, et al. Diabetes abrogates sex differences and aggravates cardiometabolic risk in postmenopausal women. Cardiovasc Diabetol. (2013) 12:61. doi: 10.1186/1475-2840-12-61

3. Zendedel A, Mönnink F, Hassanzadeh G, Zaminy A, Ansar MM, Habib P, et al. Estrogen attenuates local inflammasome expression and activation after spinal cord injury. Mol Neurobiol. (2018) 55:136475. doi: 10.1007/s12035-017-0400-2

4. Tiano JP1, Mauvais-Jarvis F. Importance of oestrogen receptors to preserve functional $\beta$-cell mass in diabetes. Nat Rev Endocrinol. (2012) 8:34251. doi: $10.1038 /$ nrendo.2011.242

5. Liu S, Le May C, Wong WP, Ward RD, Clegg DJ, Marcelli M, et al. Importance of extranuclear estrogen receptor- $\alpha$ and membrane $\mathrm{G}$ proteincoupled estrogen receptor in pancreatic islet survival. Diabetes. (2009) 58:2292-302. doi: 10.2337/db09-0257

6. Kumar R, Balhuizen A, Amisten S, Lundquist I, Salehi A. Insulinotropic and antidiabetic effects of $17 \beta$-estradiol and the GPR30 agonist G-1 on human pancreatic islets. Endocrinology. (2011) 152:2568-79. doi: 10.1210/en.2010-1361

7. Sharma G, Prossnitz ER. Mechanisms of estradiol-induced insulin secretion by the $G$ protein-coupled estrogen receptor GPR30/GPER in pancreatic $\beta$-cells. Endocrinology. (2011) 152:3030-9. doi: 10.1210/en.2011-0091

8. Liu S1, Kilic G, Meyers MS, Navarro G, Wang Y, Oberholzer J, et al. Oestrogens improve human pancreatic islet transplantation in a mouse model of insulin deficient diabetes. Diabetologia. (2013) 56:37081. doi: $10.1007 / \mathrm{s} 00125-012-2764-1$

9. Peixoto P, Aires RD, Lemos VS, Bissoli NS, Santos RLD. GPER agonist dilates mesenteric arteries via PI3K-Akt-eNOS and potassium channels in both sexes. Life Sci. (2017) 183:21-7. doi: 10.1016/j.lfs.2017.06.020

10. Guerrero M, Ferrín G, Rodríguez-Perálvarez M, González-Rubio S, Sánchez-Frías M, Amado V, et al. mTOR expression in liver transplant candidates with hepatocellular carcinoma: impact on histological features and tumour recurrence. Int J Mol Sci. 20 (2019) 20:E336. doi: 10.3390/ijms20 020336

11. Cui L, Liu M, Chang X, Sun, K. The inhibiting effect of the Coptis chinensis polysaccharide on the type II diabetic mice. Biomed Pharmacother. (2016) 81:111-9. doi: 10.1016/j.biopha.2016.03.038

12. Solmaz V, Çınar BP, Yiğittürk G, Özlece HK, Avni Eroglu H, Tekatas A, et al. Neuroprotective effects of octreotide on diabetic neuropathy
(Ethic No. 17012) and all experimental operations were complied with Guide for Laboratory Animal Care and Use and Animal Welfare Act. All applicable institutional and governmental regulations concerning the ethical use of animals were followed.

\section{AUTHOR CONTRIBUTIONS}

$\mathrm{CB}$ and $\mathrm{YZ}$ designed the experiments and wrote the manuscript. $\mathrm{CB}, \mathrm{BB}, \mathrm{QG}$, and $\mathrm{SL}$ carried out the experiments. $\mathrm{CB}$ and $\mathrm{BB}$ collected and analyzed the data.

\section{ACKNOWLEDGMENTS}

The present study was supported by the National Natural Science Foundation of China (grant no. 81470998, 81071460, and 81271996).

in rats. Biomed Pharmacother. (2017) 89:468-72. doi: 10.1016/j.biopha 2017.02.027

13. Yang HJ, Kim MJ, Kwon DY, Kim DS, Zhang T, Ha C, et al. Combination of aronia, red ginseng, shiitake mushroom and nattokinase potentiated insulin secretion and reduced insulin resistance with improving gut microbiome dysbiosis in insulin deficient type 2 diabetic rats. Nutrients. (2018) 10:E948. doi: 10.3390/nu10070948

14. Zambrana S, Lundqvist LCE, Veliz V, Catrina SB, Gonzales E, Östenson CG. Amaranthus caudatus stimulates insulin secretion in GotoKakizaki rats, a model of diabetes mellitus type 2. Nutrients. (2018) 10:94. doi: 10.3390/nu10010094

15. Wei Y, Gao J, Qin L, Xu Y, Wang D, Shi H, et al. Tanshinone I alleviates insulin resistance in type 2 diabetes mellitus rats through IRS-1 pathway. Biomed Pharmacother. (2017) 93:352-8. doi: 10.1016/j.biopha.2017.06.040

16. Dendo M, Maeda H, Yamagata Y, Murayama K, Watanabe $\mathrm{K}$, Imura $\mathrm{T}$, et al. Synergistic effect of neutral protease and clostripain on rat pancreatic islet isolation. Transplantation. (2015) 99:1349-55. doi: 10.1097/TP.0000000000000662

17. Beleznai T, Bagi Z. Activation of hexosamine pathway impairs nitric oxide (NO)-dependent arteriolar dilations by increased protein O -GlcNAcylation. Mol Carcinog. (2012) 56:115-21. doi: 10.1016/j.vph.2011.11.003

18. Zhang L, Zhao Y, Guo L. $17 \beta$-estradiol protects INS-1 insulinoma cells from mitophagy via $G$ protein-coupled estrogen receptors and the PI3K/Akt signaling pathway. Int J Mol Med. (2018) 41:3470. doi: 10.3892/ijmm.2018.3470

19. Protzek AO, Costa-Junior JM, Rezende LF, Santos GJ, Araujo TG, Vettorazzi JF, et al. Augmented $\beta$-cell function and mass in glucocorticoidtreated rodents are associated with increased islet $\operatorname{Ir}-\beta / \mathrm{AKT} / \mathrm{mTOR}$ and decreased AMPK/ACC and AS160 signaling. Int J Endocrinol. (2014) 2014:983453. doi: $10.1155 / 2014 / 983453$

20. Rafacho A, Ribeiro DL, Boschero AC, Taboga SR, Bosqueiro JR. Increased pancreatic islet mass is accompanied by activation of the insulin receptor substrate-2/serine-threonine kinase pathway and augmented cyclin D2 protein levels in insulin-resistant rats. Int J Exp Pathol. (2008) 89:26475. doi: 10.1111/j.1365-2613.2008.00588.x

21. Rafacho A, Cestari TM, Taboga SR, Boschero AC, Bosqueiro JR. High doses of dexamethasone induce increased $\beta$-cell proliferation in pancreatic rat islets. Am J Physiol Endocrinol Metab. (2009) 296:E681-9. doi: 10.1152/ajpendo.90931.2008

22. Rafacho A, Roma LP, Taboga SR, Boschero AC, Bosqueiro JR. Dexamethasone-induced insulin resistance is associated with increased connexin 36 mRNA and protein expression in pancreatic rat islets. Can J Physiol Pharmacol. (2007) 85:536-45. doi: 10.1139/Y07-037 
23. Terauchi Y, Takamoto I, Kubota N, Matsui J, Suzuki R, Komeda K, et al. Glucokinase and IRS-2 are required for compensatory $\beta$ cell hyperplasia in response to high-fat diet-induced insulin resistance. J Clin Invest. (2007) 117:246-57. doi: 10.1172/JCI17645

24. Yan Z, Ley SH, Hu RE. Global aetiology and epidemiology of type 2 diabetes mellitus and its complications. Nat Rev Endocrinol. (2017) 14:8898. doi: 10.1038/nrendo.2017.151

25. Krag MØ, Hasselbalch L, Siersma V, Nielsen ABS, Reventlow S, Malterud $\mathrm{K}$, et al. The impact of gender on the long-term morbidity and mortality of patients with type 2 diabetes receiving structured personal care: a 13 year follow-up study. Diabetologia. (2016) 59:275-85. doi: 10.1007/s00125-015-3804-4

26. Dai B, Wu Q, Zeng C, Zhang J, Cao L, Xiao Z, et al. The effect of Liuwei Dihuang decoction on PI3K/Akt signaling pathway in liver of type 2 diabetes mellitus (T2DM) rats with insulin resistance. J Ethnopharmacol. (2016) 192:382-9. doi: 10.1016/j.jep.2016.07.024

27. Keane KN, Cruzat VF, Carlessi R, De Bittencourt PIH, Newsholme P. Molecular events linking oxidative stress and inflammation to insulin resistance and $\beta$-cell dysfunction. Oxid Med Cell Longev. (2015) 2015:181643. doi: 10.1155/2015/181643

28. Morris A. Diabetes: peripheral A $\beta$ linked to pathogenesis of T2DM. Nature reviews. Endocrinology. (2017) 13:564. doi: 10.1038/nrendo.2017.118

29. Gastaldelli A, Gaggini M, Defronzo JD. Role of adipose tissue insulin resistance in the natural history of T2DM: results from the San Antonio metabolism study. Diabetes. (2017) 66:815. doi: 10.2337/db16-1167

30. Pingitore A, Caroleo MC, Cione E, Castañera GR, Huang GC, Persaud JM, et al. Fine tuning of insulin secretion by release of nerve growth factor from mouse and human islet $\beta$-cells. Mol Cell Endocrinol. (2016) 436:2332. doi: 10.1016/j.mce.2016.07.014

31. Al-Daghri NM, Alkharfy KM, Al-Othman A, El-Kholie E, Moharram O, Alokail MS, et al. Vitamin D supplementation as an adjuvant therapy for patients with T2DM: an 18-month prospective interventional study. Cardiovasc Diabetol. (2012) 11:85. doi: 10.1186/1475-2840-11-85

32. Choi SB, Jang JS, Park S. Estrogen and exercise may enhance $\beta$-cell function and mass via insulin receptor substrate 2 induction in ovariectomized diabetic rats. Endocrinology. (2005) 146:4786-94. doi: 10.1210/en.2004-1653

33. Mudaliar S, Armstrong DA, Mavian AA, O'Connor-Semmes R, Mydlow PK, Ye J, et al. Remogliflozin etabonate, a selective inhibitor of the sodium-glucose transporter 2, improves serum glucose profiles in type 1 diabetes. Diabetes Care. (2012) 35:2198-200. doi: 10.2337/dc12-0508

34. Norton L, Shannon CE, Fourcaudot M, Hu C, Wang N, Ren W, et al. Sodiumglucose co-transporter (SGLT) and glucose transporter (GLUT) expression in the kidney of type 2 diabetic subjects. Diabetes Obes Metab. (2017) 19:13226. doi: 10.1111/dom. 13003

35. Basco D, Zhang Q, Salehi A, Tarasov A, Dolci W, Herrera P, et al. $\alpha$-cell glucokinase suppresses glucose-regulated glucagon secretion. Nat Commun. (2018) 9:546. doi: 10.1038/s41467-018-03034-0

36. Abbasi NN, Purslow PP, Tosh SM, Bakovic NR. Oat $\beta$-glucan depresses SGLT1- and GLUT2-mediated glucose transport in intestinal epithelial cells (IEC-6). Nutr Res. (2016) 36:541-52. doi: 10.1016/j.nutres.2016.02.004

37. Kellett GL, Brotlaroche E, Mace OJ, Leturque N. Sugar absorption in the intestine: the role of GLUT2. Annu Rev Nutr. (2008) 28:3554. doi: 10.1146/annurev.nutr.28.061807.155518

38. Jin ES, Jones JG, Merritt M, Burgess SC, Malloy CR, Sherry AB. Glucose production, gluconeogenesis, and hepatic tricarboxylic acid cycle fluxes measured by nuclear magnetic resonance analysis of a single glucose derivative. Anal Biochem. (2004) 327:149-55. doi: 10.1016/j.ab.2003. 12.036

39. Finol-Urdaneta RK, Remedi MS, Raasch W, Becker S, Clark RB, Strüver $\mathrm{N}$, et al. Block of Kv1.7 potassium currents increases glucose-stimulated insulin secretion. EMBO Mol Med. (2012) 4:424-34. doi: 10.1002/emmm. 201200218
40. Xian HM, Che H, Qin Y, Yang F, Meng SY, Li XG, et al. Coriolus versicolor aqueous extract ameliorates insulin resistance with PI3K/Akt and p38 MAPK signaling pathways involved in diabetic skeletal muscle. Phytother Res. (2018) 32:551-60. doi: 10.1002/ptr.6007

41. Elghazi L, Blandino-Rosano M, Alejandro E, Cras-Méneur C, Bernal-Mizrachi E. Role of nutrients and mTOR signaling in the regulation of pancreatic progenitors development. Mol Metab. (2017) 6:560-73. doi: 10.1016/j.molmet.2017.03.010

42. Mourouzis I, Giagourta I, Galanopoulos G, Mantzouratou P, Kostakou E, Kokkinos AD, et al. Thyroid hormone improves the mechanical performance of the post-infarcted diabetic myocardium: a response associated with upregulation of Akt/mTOR and AMPK activation. Metab Clin Exp. (2013) 62:1387-93. doi: 10.1016/j.metabol.2013.05.008

43. Huang W, Peng Y, Kiselar J, Zhao X, Albaqami A, Mendez D, et al. Multidomain architecture of estrogen receptor reveals interfacial cross-talk between its DNA-binding and ligand-binding domains. Nat Commun. (2018) 9:3520. doi: 10.1038/s41467-018-06034-2

44. Kondo K, Morino K, Nishio Y, Kondo M, Nakao K, Nakagawa F, et al. A fish-based diet intervention improves endothelial function in postmenopausal women with type 2 diabetes mellitus: a randomized crossover trial. Metab Clin Exp. (2014) 63:930-40. doi: 10.1016/j.metabol.2014.04.005

45. Jia M, Dahlman-Wright K, Gustafsson JÅ. Estrogen receptor $\alpha$ and $\beta$ in health and disease. Best Pract Res Clin Endocrinol Metab. (2015) 29:55768. doi: 10.1016/j.beem.2015.04.008

46. Feldman RD, Limbird LE. GPER (GPR30): a nongenomic receptor (GPCR) for steroid hormones with implications for cardiovascular disease and cancer. Ann Rev Pharmacol Toxicol. (2017) 57:567-84. doi: 10.1146/annurev-pharmtox-010716-104651

47. Petrone AB, Gatson JW, Simpkins JW, Reed MN. Non-feminizing estrogens: a novel neuroprotective therapy. Mol Cell Endocrinol. (2014) 389:407. doi: 10.1016/j.mce.2013.12.017

48. O'Mahony F, Razandi M, Pedram A, Harvey BJ, Levin ER. Estrogen modulates metabolic pathway adaptation to available glucose in breast cancer cells. $\mathrm{Mol}$ Endocrinol. (2012) 26:2058-70. doi: 10.1210/me.2012-1191

49. Pisano A, Santolla MF, De Francesco EM, De Marco P, Rigiracciolo DC, Perri MG, et al. GPER, IGF-IR, and EGFR transduction signaling are involved in stimulatory effects of zinc in breast cancer cells and cancer-associated fibroblasts. Mol Carcinogenesis. (2017) 56:580-93. doi: 10.1002/mc.22518

50. Vogel H, Wolf S, Rabasa C, Rodriguez-Pacheco F, Babaei CS, Stöber F, et al. GLP-1 and estrogen conjugate acts in the supramammillary nucleus to reduce food-reward and body weight. Neuropharmacology. (2016) 110:396406. doi: 10.1016/j.neuropharm.2016.07.039

51. Tandon R, Luxami V, Dosanjh HS, Tandon N, Paul K. Insulin therapy for diabetes epidemic: a patent review. Curr Drug Deliv. (2018) 15:77794. doi: 10.2174/1567201815666180228161659

52. Force USPST, Grossman DC, Curry SJ, Owens DK, Barry MJ, et al. Hormone therapy for the primary prevention of chronic conditions in postmenopausal women: US preventive services task force recommendation statement. JAMA. (2017) 318:2224-33. doi: 10.1001/jama. 2017.18261

Conflict of Interest Statement: The authors declare that the research was conducted in the absence of any commercial or financial relationships that could be construed as a potential conflict of interest.

Copyright (c) 2019 Bian, Bai, Gao, Li and Zhao. This is an open-access article distributed under the terms of the Creative Commons Attribution License (CC BY). The use, distribution or reproduction in other forums is permitted, provided the original author(s) and the copyright owner(s) are credited and that the original publication in this journal is cited, in accordance with accepted academic practice. No use, distribution or reproduction is permitted which does not comply with these terms. 